\title{
High yield lipase-catalyzed synthesis of Engkabang fat esters for the cosmetic industry.
}

\begin{abstract}
Engkabang fat esters were produced via alcoholysis reaction between Engkabang fat and oleyl alcohol, catalyzed by Lipozyme RM IM. The reaction was carried out in a $500 \mathrm{ml}$ Stirred tank reactor using heptane and hexane as solvents. Response surface methodology (RSM) based on a four-factor-five-level Central composite design (CCD) was applied to evaluate the effects of synthesis parameters, namely temperature, substrate molar ratio (oleyl alcohol: Engkabang fat), enzyme amount and impeller speed. The optimum yields of $96.2 \%$ and $91.4 \%$ were obtained for heptane and hexane at the optimum temperature of $53.9{ }^{\circ} \mathrm{C}$, impeller speeds of 309.5 and $309.0 \mathrm{rpm}$, enzyme amounts of 4.82 and $5.65 \mathrm{~g}$ and substrate molar ratios of 2.94 and 3.39:1, respectively. The actual yields obtained compared well with the predicted values of $100.0 \%$ and $91.5 \%$, respectively. Meanwhile, the properties of the esters show that they are suitable to be used as ingredient for cosmetic applications.
\end{abstract}

Keyword: Engkabang fat esters; Response surface methodology; Central composite design; Alcoholysis; Stirred tank reactor. 